\title{
HEAVY METAL CONTAMINATION AND ECOLOGICAL RISK ASSESSMENT IN THE SOIL OF TANNERY INDUSTRY AT SAVAR
}

\author{
Sabiha Momtaz Tisha ${ }^{1 *}$ and Tasnia Rahman Chowdhury ${ }^{1}$ \\ Department of Environment, Water Resources and Coastal Engineering, \\ Military Institute of Science and Technology, Dhaka, Bangladesh
}

\author{
Md. Delwar Hossain \\ Department of Civil Engineering, Bangladesh University of \\ Engineering and Technology, Dhaka, Bangladesh
}

\begin{abstract}
Heavy metal contamination in soil is considered a global crisis and its bulk proportion are in developing countries like Bangladesh. Five heavy metals such as $\mathrm{Cd}, \mathrm{Cr}, \mathrm{Pb}, \mathrm{Cu}$ and $\mathrm{Ni}$ were investigated in the soil of Savar tannery industrial estate. The decreasing trend of metals was observed in soil as $\mathrm{Cr}>\mathrm{Cu}>\mathrm{Ni}>\mathrm{Pb}>\mathrm{Cd}$. According to US EPA guideline, $\mathrm{Cr}$ was heavily polluted at the selected locations. $\mathrm{Cu}$ was highly polluted, whereas $\mathrm{Cd}$ and $\mathrm{Pb}$ were not polluted and $\mathrm{Ni}$ was moderately polluted. On the basis of Pearson's correlation $\mathrm{Cd}-\mathrm{Pb}, \mathrm{Cd}-\mathrm{Cu}, \mathrm{Cu}-\mathrm{Ni}, \mathrm{Ni}-\mathrm{Cu}, \mathrm{Ni}-$ $\mathrm{Pb}$ were significantly correlated. From the pollution index, metal pollution of sediments was found in the order as $\mathrm{Cr}>\mathrm{Cu}>\mathrm{Pb}>\mathrm{Cd}$. Degree of contamination and modified degree of contamination were higher in the dumping zones. The geo-accumulation index for $\mathrm{Cr}$ showed moderate to extremely contaminated. Ecological risk arrayed in the order of $\mathrm{Cr}>\mathrm{Cu}>\mathrm{Ni}>\mathrm{Pb}>\mathrm{Cd}$ in the soil of study area. Geographic information system (GIS) was also used to map the spatial distribution of heavy metal contamination in the soil. This study recommended that continuous monitoring of heavy metal contamination should be directed to assess their risk in the soil of tannery industry at Savar.
\end{abstract}

Keywords: Tannery;Contamination Factor;Geo accumulation Index; Ecological Risk Index; Spatial Distribution

\section{Introduction}

Heavy metals are persistent, toxic and bio accumulative and some of the metals are carcinogenic. The persistence of heavy metals in soils is a long process [1]. As soil is a crucial component of rural and urban environments, the role of heavy metals in the soil system is increasingly becoming an issue of global concern [2]. There is a gradual increase in industrial waste in Bangladesh and, due to rapid industrialization; these waste products have caused significant pollution of the air, water and soil, thereby polluting the atmosphere [3]. Pollution of the natural environment by heavy metals is a universal problem because these metals are indestructible and most of them have toxic effects on living organisms, when permissible concentration levels are exceeded [4]. Leather industry, one of the polluting industries because of generation of huge amount of liquid and solid wastes, also emits obnoxious smell because of degradation of proteins material of skin and generation of gases such as $\mathrm{NH}_{3}, \mathrm{H}_{2} \mathrm{~S}$ and $\mathrm{CO}_{2}$ [5].
The Buriganga River received waste from hundreds of Hazaribagh tanneries until 2018 [6]. The Government of Bangladesh (GOB) tried to minimize pollution and promote development by moving the tannery industry upstream to a new tannery town in the Savar on the banks of the Dhaleswari River, which is hydraulically linked to Buriganga [7]. The Dhaleswari river had already seen increased pollution levels ever since the estate was set up near the river. The accumulated solid waste created in the last year currently remains dumped at a pond at the tannery estate's boundaries. The Government have also provided a centralized effluent treatment plant for effluent clean [8]. The wastes include the high level of concentrated chromium and salt because of faulty installation of central effluent treatment plant (CETP). Thus, the sediment is getting polluted. The primary objective of the study was to assess the heavy metal and radioactive metal pollution level of the Dhaleswari River sediments. In this study total concentrations of 5 trace elements $(\mathrm{Cr}, \mathrm{Ni}, \mathrm{Cu}, \mathrm{Cd}, \mathrm{Pb})$ in the riverside of Dhaleswari river of industrial zone and the dumping zone were determined. 
The objectives are to identify the major source of pollution of TIED (Tannery Industrial Estate Dhaka) Zone; to assess the heavy metal contamination of the sediment; to compare the data analysis according to USEPA guideline; to evaluate the level of contamination of soil of the waste disposal site using various indices and to distribute the heavy metals and various indices spatially and to know the variation of metals in the soil of the disposal site.

\section{Experiment}

\subsection{Study Area and Sediment Collection}

The soil samples were collected from different eight locations near CETP which are designated as L1, L-2, L-3, L-4, L-5, L-6, L-7, L-8 to get an idea about the soil quality all over the TIED zone of Dhaleswari River. L-1, L-2, L-3 samples are from the riverside areas of the industrial zone. Here, L-3 was collected from the midpoint of L-1 and L-2. Other five soil samples are the soil of dumping zone. The latitude and longitude of all the soil sampling locations were recorded.

Table 1

GPS location of the site

\begin{tabular}{lll}
\hline Sample Location & Latitude & Longitude \\
\hline L-1 & $23^{\circ} 46^{\prime} 37.42^{\prime \prime}$ & $90^{\circ} 14^{\prime} 23.31^{\prime \prime}$ \\
L-2 & $23^{\circ} 46^{\prime} 33.41^{\prime \prime}$ & $90^{\circ} 14^{\prime} 21.84^{\prime \prime}$ \\
L-3 & $23^{\circ} 46^{\prime} 35.44^{\prime \prime}$ & $90^{\circ} 14^{\prime} 22.45^{\prime \prime}$ \\
L-4 & $23^{\circ} 46^{\prime} 25.09^{\prime \prime}$ & $90^{\circ} 14^{\prime} 24.74^{\prime \prime}$ \\
L-5 & $23^{\circ} 46^{\prime} 24.08^{\prime \prime}$ & $90^{\circ} 14^{\prime} 25.28^{\prime \prime}$ \\
L-6 & $23^{\circ} 46^{\prime} 24.38^{\prime \prime}$ & $90^{\circ} 14^{\prime} 23.51^{\prime \prime}$ \\
L-7 & $23^{\circ} 46^{\prime} 24.58^{\prime \prime}$ & $90^{\circ} 14^{\prime} 21.99^{\prime \prime}$ \\
L-8 & $23^{\circ} 46^{\prime} 23.59^{\prime \prime}$ & $90^{\circ} 14^{\prime} 21.71^{\prime \prime}$ \\
\hline
\end{tabular}

The soil samples were collected in August 2019. The water level of Dhaleswari river was very high as it was monsoon season. So, the moisture content of the samples was very high.

\subsection{Sampling Technique and Preparation}

The soil samples were collected from the bottom of the borehole. The soil samples were taken in large polythene bags and eventually transported to the laboratory. Then the soil samples were oven dried. After that the samples were fully crushed to the finest possible fraction and passed through sieve no \#16. $1 \mathrm{~g}$ of this crushed sediment was then transferred to a sample beaker and acid digestion process was followed. Then the metal analysis was performed by Atomic Absorption Spectroscopy with the use of standards to allow determination of metal concentrations within each sample.

\subsection{Data Analysis}

To assess the heavy metal contamination different indices were used. In this study, to identify the level of contamination of soil, the values for various indices were then compared with the allowable limit published by different researchers as well as discussed in the following article.

\subsubsection{Pollution Load Index}

For each contaminant the PLI is calculated using the formula proposed by Wilson and Jeffrey [9]

$\mathrm{PLI}=$ ant $i \log _{10}\left\{1-\left(\frac{C-B}{T-B}\right)\right\}$

$\mathrm{B}$ is the baseline value - not contaminated; $\mathrm{T}$ the threshold, minimum concentrations associated with degradation or changes in the quality of the estuarine system; $\mathrm{C}$ the concentration of the pollutant. For each place the PLI calculation takes into account all the $n$ contaminants:

$\mathrm{PLI}=\left(\mathrm{PLI}_{1} \times \mathrm{PLI}_{2} \times \mathrm{PLI}_{3} \ldots \mathrm{PLI}_{\mathrm{n}}\right)^{\mathrm{n}}$

PLI varies from 10 (unpolluted) to 0 (highly polluted).

\subsubsection{Contamination Factor}

Contamination factor $(\mathrm{CF})$ is considered to be a simple and essential too in monitoring the heavy metal contamination. It is individual for each metal as it is the ratio between the measured concentration and the background value of the heavy metal. CF was computed using following equation:

$C F=C_{\text {metal }} / C_{\text {background }}$

CF values were demonstrated by Hakanson [10]

Table 2

Background concentration of some heavy metals

\begin{tabular}{lccccc}
\hline Heavy Metal & Cd & $\mathbf{C r}$ & $\mathbf{P b}$ & $\mathbf{C u}$ & $\mathbf{N i}$ \\
\hline World Surface Rock Average & 0.2 & 97 & 20 & 32 & 49 \\
\hline
\end{tabular}

Table 3

Different contamination factor (CF) for soil (Hakanson 1980)

\begin{tabular}{ll}
\hline Value & Contamination Factor level \\
\hline $\mathrm{CF}<1$ & Low contamination factor \\
$1 \leq \mathrm{CF}<3$ & Moderate contamination factor \\
$3 \leq \mathrm{CF}<6$ & Considerable contamination factor \\
$6 \geq \mathrm{CF}$ & Very high contamination factor \\
\hline
\end{tabular}

\subsubsection{Degree of Contamination}

The degree of contamination $\left(\mathrm{C}_{\mathrm{d}}\right)$ is an index to estimate the contamination range of soil by metal elements in soil. It is calculated by the sum of the contamination factor $(\mathrm{CF})$.

$\mathrm{C}_{\mathrm{d}}=\sum_{i=1}^{i=n}(C F)$ 
Table 4

Different degree of contamination $\left(\mathrm{C}_{\mathrm{d}}\right)$ for soil

\begin{tabular}{ll}
\hline Value & Class Degree of Contamination Level \\
\hline$C_{d}<8$ & Low degree of contamination \\
$8 \leq \mathrm{C}_{\mathrm{d}}<16$ & Moderate degree of contamination \\
$16 \leq \mathrm{C}_{\mathrm{d}}<32$ & Considerable degree of contamination \\
$32 \geq \mathrm{C}_{\mathrm{d}}$ & Very high degree of contamination \\
\hline
\end{tabular}

\subsubsection{Modified Contamination Degree}

It is worth noting that modified contamination degree $\left(\mathrm{mC}_{\mathrm{d}}\right)$ is a modified and generalized form of the degree of contamination which was proposed by Abrahim and Parker (2008) [11]. It is calculated by following equation:

$\mathrm{mC}_{\mathrm{d}}=1 / \mathrm{n} \sum_{i=1}^{i=n}(C F)$

The definite formula of the $\mathrm{C}_{\mathrm{d}}$ is reversed to the Seven specific metal (As, Cd, Cu, Cr, $\mathrm{Hg}$. Pb, Zn) and the organic chemical polychlorinated biphenyl (PCB) [11]. However, $\mathrm{mC}_{\mathrm{d}}$ is the more suitable for this study hence PCB was not analysis here. It indicates heavy metals as well as organic pollution. As it is classified in seven classes, it indicates more specification in identifying the degree of contamination in soil. It is widely used.

Table 5

Different modified contamination degree (mCd) for soil (Abrahim \& Parker 2008)

\begin{tabular}{ll}
\hline Value & $\begin{array}{l}\text { Class Modified Degree of } \\
\text { Contamination Level }\end{array}$ \\
\hline $\mathrm{mC}_{\mathrm{d}}<1.5$ & Nil to very low degree of contamination \\
$1.5 \leq \mathrm{mC}_{\mathrm{d}}<2$ & Low degree of contamination \\
$2 \leq \mathrm{mC}_{\mathrm{d}}<4$ & Moderate degree of contamination \\
$4 \leq \mathrm{mC}_{\mathrm{d}}<8$ & High degree of contamination \\
$8 \leq \mathrm{mC}_{\mathrm{d}}<16$ & Very high degree of contamination \\
$16 \leq \mathrm{mC}_{\mathrm{d}}<32$ & Extremely high degree of contamination \\
$\mathrm{mC}_{\mathrm{d}} \geq 32$ & Ultra-high degree of contamination \\
\hline
\end{tabular}

\subsubsection{Ecological Risk Index and Potential Ecological Risk}

Ecological risk index (ER) is used as an indicator to check the ecological risk in soil according to the toxicity of heavy metals and response factor of the environment.

The potential ecological risk Index (PERI) is used as an indicator to check the ecological risk in soil. It is a comprehensive potential ecological risk index of a contaminated site. PERI is formed by three basic parts: contamination factor (CF), toxic-response factor (TR) and ecological risk index (ER).
According to this technique, in this study, the ER and PERI were calculated using the following equations respectively

$E R=T R \times \mathrm{CF}$

$P E R I=\Sigma E R$

Here, ER is the ecological risk index of a particular metal element in soil, PERI is a comprehensive potential ecological risk index of a contaminated site; and TR is the toxic-response factor of a single metal element.

Table 6

Toxic-response factor (TR) values for metal element

\begin{tabular}{llllll}
\hline Heavy Metal & $\mathrm{Cd}$ & $\mathrm{Cr}$ & $\mathrm{Pb}$ & $\mathrm{Cu}$ & $\mathrm{Ni}$ \\
\hline Toxic Response Factor (TR) & 30 & 2 & 5 & 5 & 5 \\
\hline
\end{tabular}

The classic PERI method considers eight pollutants including PCBs, $\mathrm{Hg}, \mathrm{Cd}, \mathrm{As}, \mathrm{Pb}, \mathrm{Cu}$ and $\mathrm{Zn}$. However, in this study, it was not possible to consider PCBs and $\mathrm{Hg}$; but the metal elements of $\mathrm{Ni}$ were used. The classification of the contamination of soil for various limits of ER and PERI is provided in Table 7.

Table 7

Classification of soil contamination based on ecological risk index (ER) and potential ecological risk index (PERI)

\begin{tabular}{llll}
\hline ER & $\begin{array}{l}\text { Ecological } \\
\text { risk degree }\end{array}$ & PERI & $\begin{array}{l}\text { Ecological } \\
\text { risk degree }\end{array}$ \\
\hline $\mathrm{ER} \geq 240$ & $\begin{array}{l}\text { Extremely } \\
\text { strong }\end{array}$ & $\mathrm{PER} \geq 320$ & $\begin{array}{l}\text { Extremely } \\
\text { strong }\end{array}$ \\
$120 \leq \mathrm{ER} \leq 240$ & $\begin{array}{l}\text { Very } \\
\text { Strong }\end{array}$ & $160 \leq \mathrm{ER} \leq 240$ & $\begin{array}{l}\text { Very } \\
\text { Strong }\end{array}$ \\
$60 \leq \mathrm{ER} \leq 120$ & Strong & $80 \leq \mathrm{ER} \leq 160$ & Strong \\
$30 \leq \mathrm{ER} \leq 60$ & Moderate & $40 \leq \mathrm{ER} \leq 80$ & Moderate \\
$\leq 30$ & Slight & $\leq 40$ & Slight \\
\hline
\end{tabular}

\subsubsection{Geo Accumulation Index}

The geo-accumulation index $\left(\mathrm{I}_{\text {geo }}\right)$ is used to evaluate the degree of contamination of soil by metal elements presences in soil. In this study, $\mathrm{I}_{\text {geo }}$ was computed using the following equation proposed by Mullar [12].

$\mathrm{I}_{\mathrm{geo}}=\log _{2}\left(\frac{C n}{1.5 B n}\right)$

Where, $\mathrm{Cn}$ is the measured concentration of a particular metal element and $\mathrm{Bn}$ is the geochemical background value (average shale value) of the same metal element. The numerical number of 1.5 as constant value is used in the index calculation to account the natural variations in the environment and small anthropogenic influences. 
Table 8

Contamination classes for $\mathrm{I}_{\text {geo }}$ value

\begin{tabular}{lll}
\hline $\begin{array}{l}\mathbf{I}_{\text {geo }} \\
\text { Class }\end{array}$ & $\mathbf{I}_{\text {geo }}$ Value & Contamination Level \\
\hline 0 & $\mathrm{I}_{\text {geo }} \leq 0$ & Uncontaminated \\
1 & $0<\mathrm{I}_{\text {geo }}<1$ & $\begin{array}{l}\text { Uncontaminated to moderately } \\
\text { contaminated } \\
\text { Moderately contaminated }\end{array}$ \\
2 & $1<\mathrm{I}_{\text {geo }}<2$ & Moderately to strongly contaminated \\
3 & $2<\mathrm{I}_{\mathrm{geo}}<3$ & Strongly contaminated \\
4 & $3<\mathrm{I}_{\mathrm{geo}}<4$ & Strongly to extremely contaminated \\
5 & $4<\mathrm{I}_{\mathrm{geo}}<5$ & Extremely contaminated \\
6 & $5<\mathrm{I}_{\mathrm{geo}}$ & \\
\hline
\end{tabular}

\section{Result and Discussion}

\subsection{Metal Analysis}

Concentrations of metals in sediment samples from Dhaleswari river are presented in Table 9. As Cd has below detection level concentration in five locations, so they are considered as 0 .

Table 9

Concentration of different heavy metal $(\mathrm{mg} / \mathrm{kg})$

\begin{tabular}{llllll}
\hline $\begin{array}{l}\text { Sample } \\
\text { Location }\end{array}$ & $\begin{array}{l}\mathbf{C d} \\
(\mathbf{m g} / \mathbf{k g})\end{array}$ & $\begin{array}{l}\mathbf{C r} \\
(\mathbf{m g} / \mathbf{k g})\end{array}$ & $\begin{array}{l}\mathbf{P b} \\
(\mathbf{m g} / \mathbf{k g})\end{array}$ & $\begin{array}{l}\mathbf{C u} \\
(\mathbf{m g} / \mathbf{k g})\end{array}$ & $\begin{array}{l}\mathbf{N i} \\
(\mathbf{m g} / \mathbf{k g})\end{array}$ \\
\hline L -1 & 0.07 & 1309.8 & 33.0 & 216.3 & 47.1 \\
L-2 & 0.05 & 299.7 & 32.4 & 63.1 & 49.2 \\
L-3 & 0 & 900.9 & 3.4 & 13.1 & 13.5 \\
L-4 & 0 & 5326.4 & 8.7 & 36.9 & 12.4 \\
L-5 & 0.01 & 344.6 & 25.9 & 173.4 & 28.8 \\
L-6 & 0 & 3025.5 & 9.8 & 15.5 & 10.4 \\
L-7 & 0 & 1742.3 & 7.0 & 17.4 & 11.9 \\
L -8 & 0 & 8093.8 & 18.9 & 48.3 & 12.0 \\
Mean & 0.02 & 2630.4 & 17.4 & 73.0 & 23.2 \\
Max & 0.07 & 8093.8 & 33.0 & 216.3 & 49.2 \\
Min & 0 & 299.7 & 3.4 & 13.1 & 10.4 \\
SD & 0.03 & 2763.4 & 11.8 & 78.0 & 16.5 \\
\hline
\end{tabular}

In the Riverside industrial zone (L-1, L-2, L-3), the max concentration of $\mathrm{Cd}, \mathrm{Cu}, \mathrm{Pb}$ and $\mathrm{Ni}$ is found whereas in the dumping zone (L-4, L-5, L-6, L-7, L-8) the max concentration of $\mathrm{Cr}$ is found. The concentration of metals for L-1 in sediments has the trend: $\mathrm{Cr}>\mathrm{Cu}>\mathrm{Ni}>\mathrm{Pb}>\mathrm{Cd}$. Graphical representation of $\mathrm{Cr}$ and $\mathrm{Cu}$ is given.

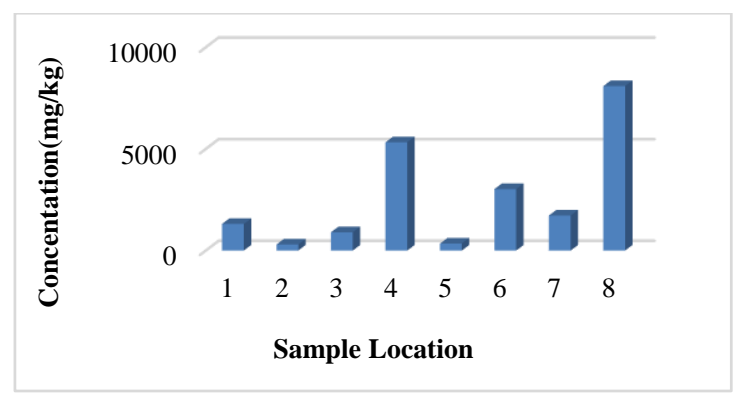

Fig. 1: Concentration Graph of $\mathrm{Cr}(\mathrm{mg} / \mathrm{kg})$
From Fig. 1, it can be understood that among the 8 locations the $\mathrm{Cr}$ concentration is high in dumping zones.

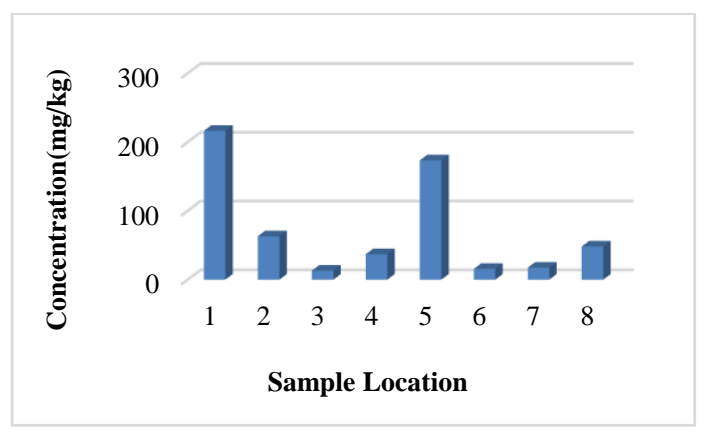

Fig. 2: Concentration Graph of $\mathrm{Cu}(\mathrm{mg} / \mathrm{kg})$

In Fig. 2, $\mathrm{Cu}$ concentration is high at the $\mathrm{L}-1$ and the least concentration is at L-3.

\subsection{Result of Soil Contamination using various Indices}

\subsubsection{Pollution Load Index}

Pollution load index value of 0 indicates highly polluted while PLI value of 10 indicates unpolluted sediments. Values within 0 to 10 are for moderately polluted sediments. Metals contributing in pollution of sediments are arranged in the order as $\mathrm{Cr}>\mathrm{Cu}>\mathrm{Pb}>\mathrm{Cd}$. It can be observed from Table 10 .

Table 10

Pollution load index for Dhaleswari river soil (Wilson and Jeffrey, 1987)

\begin{tabular}{llllll}
\hline $\begin{array}{l}\text { Sample } \\
\text { location }\end{array}$ & $\begin{array}{l}\mathrm{Cd} \\
(\mathrm{mg} / \mathrm{kg})\end{array}$ & $\begin{array}{l}\mathrm{Cr} \\
(\mathrm{mg} / \mathrm{kg})\end{array}$ & $\begin{array}{l}\mathrm{Pb} \\
(\mathrm{mg} / \mathrm{kg})\end{array}$ & $\begin{array}{l}\mathrm{Cu} \\
(\mathrm{mg} / \mathrm{kg})\end{array}$ & $\begin{array}{l}\text { Combined } \\
\mathrm{PLI}\end{array}$ \\
\hline $\mathrm{L}-1$ & 27.0 & 0 & 5.6 & 0 & 0 \\
$\mathrm{~L}-2$ & 28.1 & 0 & 5.6 & 0.51 & 0 \\
$\mathrm{~L}-3$ & 44.9 & 0 & 11.8 & 6.60 & 0 \\
$\mathrm{~L}-4$ & 37.9 & 0 & 10.3 & 1.96 & 0 \\
$\mathrm{~L}-5$ & 30.6 & 0 & 6.7 & 0 & 0 \\
$\mathrm{~L}-6$ & 52.5 & 0 & 10.0 & 5.83 & 0 \\
$\mathrm{~L}-7$ & 54.2 & 0 & 10.8 & 5.31 & 0 \\
$\mathrm{~L}-8$ & 54.0 & 0 & 8.0 & 1.09 & 0 \\
\hline
\end{tabular}

\subsubsection{Contamination Factor, Degree of Contamination and Modified Contamination Degree}

According to Table 11, Cd is found less than 1 for all sites that indicates low contamination factor. $\mathrm{Cr}$ is in the range of moderate to very high contamination factor. For $\mathrm{Cr}, \mathrm{CF}$ value indicates moderate contamination factor for L-2 and L-5 site. L-3 value of $\mathrm{Cr}$ is in considerable contamination factor and rest of the sites (L-1,L-4,L-6,L-7,L-8) are very high in contamination factor for $\mathrm{Cr}$. $\mathrm{Pb}$ is in low 
contamination factor in L-3,L-4,L-6,L-7,L-8 and moderate contamination factor in $\mathrm{L}-1, \mathrm{~L}-2, \mathrm{~L}-5 . \mathrm{Cu}$ is in low contamination factor in L-3,L-6,L-7; moderate contamination factor in L-2,L-4.L-5,L-8 and very high in L-1. Ni is found less than in almost all the site which means low contamination factor. Only in L-2 the value is 1 (moderate contamination factor).

\section{Table 11}

Contamination Factor, Degree of Contamination and Modified Contamination Degree of different soil

\begin{tabular}{|c|c|c|c|c|c|c|c|}
\hline \multirow{2}{*}{ 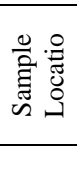 } & \multicolumn{5}{|c|}{$\begin{array}{l}\text { Contamination factor of single } \\
\text { metal }(\mathrm{CF})\end{array}$} & \multirow{2}{*}{ 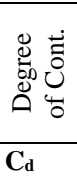 } & \multirow{2}{*}{ 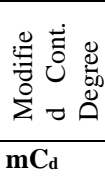 } \\
\hline & Cd & $\mathbf{C r}$ & $\mathbf{P b}$ & $\mathbf{C u}$ & $\mathbf{N i}$ & & \\
\hline L-1 & $\begin{array}{l}0.3 \\
5\end{array}$ & 13.5 & 1.65 & 6.76 & 0.96 & 23.2 & 4.64 \\
\hline L-2 & $\begin{array}{l}0.2 \\
6\end{array}$ & 3.1 & 1.62 & 1.97 & 1.00 & 7.9 & 1.59 \\
\hline L-3 & 0 & 9.3 & 0.17 & 0.41 & 0.27 & 10.1 & 2.03 \\
\hline L-4 & 0 & 54.9 & 0.44 & 1.15 & 0.25 & 56.8 & 11.35 \\
\hline L-5 & $\begin{array}{l}0.0 \\
7\end{array}$ & 3.6 & 1.30 & 5.42 & 0.59 & 10.9 & 2.19 \\
\hline L-6 & 0 & 31.2 & 0.49 & 0.49 & 0.21 & 32.4 & 6.48 \\
\hline L-7 & 0 & 17.8 & 0.35 & 0.54 & 0.24 & 18.9 & 3.78 \\
\hline L-8 & 0 & 83.4 & 0.9 & 1.51 & 0.24 & 86.1 & 17.23 \\
\hline
\end{tabular}

The degree of contamination $\left(\mathrm{C}_{\mathrm{d}}\right)$ was proposed by Hakanson (1980). It is calculated by the sum of the contamination factor (CF). It is computed separately for each sampling site. Degree of contamination is low in L-2; moderate in L-3, L-5; considerable in L-1, L-7 and very high in L-4, L-6, L-8.

According to $\mathrm{mC}_{\mathrm{d}}, \mathrm{L}-2$ has low contamination factor; L-3, L-5 and L-7 have moderate contamination factor; L-1 and L-6 have high contamination factor; L4 has very high contamination factor and L-8 has extremely high contamination factor.

\subsubsection{Ecological Risk Index and Potential Ecological Risk}

Ecological risk index (ER) is for a single metal element.

Table 12

Ecological Risk and Potential Ecological Risk Index of various metal

\begin{tabular}{ccccccc}
\hline $\begin{array}{c}\text { Sample } \\
\text { Location }\end{array}$ & \multicolumn{7}{c}{ Ecological Risk Index } & & PERI \\
& $\mathrm{Cd}$ & $\mathrm{Cr}$ & $\mathrm{Pb}$ & $\mathrm{Cu}$ & $\mathrm{Ni}$ & $($ PERI $)$ \\
& $(\mathrm{ER})$ & $(\mathrm{ER})$ & $(\mathrm{ER})$ & $(\mathrm{ER})$ & $(\mathrm{ER})$ & \\
$\mathrm{L}-1$ & 0 & 654.9 & 6.59 & 43.3 & 9.41 & 714.2 \\
$\mathrm{~L}-2$ & 0 & 149.8 & 6.48 & 12.6 & 9.83 & 178.7 \\
$\mathrm{~L}-3$ & 0 & 450.4 & 0.68 & 2.63 & 2.69 & 456.4 \\
$\mathrm{~L}-4$ & 0 & 2663.2 & 1.74 & 7.37 & 2.48 & 2674.79 \\
$\mathrm{~L}-5$ & 0 & 172.3 & 5.19 & 34.69 & 5.77 & 217.9 \\
$\mathrm{~L}-6$ & 0 & 1512.7 & 1.96 & 3.10 & 2.07 & 1519.8 \\
$\mathrm{~L}-7$ & 0 & 862.1 & 1.40 & 3.48 & 2.38 & 869.4 \\
$\mathrm{~L}-8$ & 0 & 4046.9 & 3.79 & 9.66 & 2.4 & 4062.7 \\
\hline
\end{tabular}

The severity of pollution of the five heavy metals decreased in the following sequence: $\mathrm{ER}(\mathrm{Cr})>\mathrm{ER}(\mathrm{Cu})>\mathrm{ER}(\mathrm{Ni})>\mathrm{ER}(\mathrm{Pb})>\mathrm{ER}(\mathrm{Cd})$.

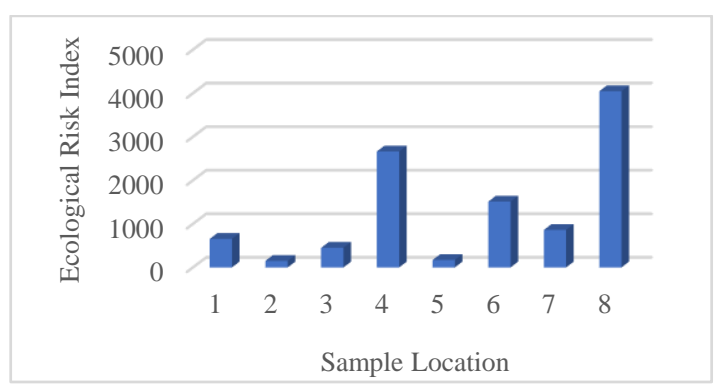

Fig. 3: Ecological Risk of $\mathrm{Cr}$

According to these data, $\mathrm{Cr}$ posed an extremely strong ecological risk at six sites and a very strong risk at two sites in the TIED zone. Due to Cr, the sites L-2, L-5 is very strong in ecological risk and L-1, L-3, L-4, L-6, L-7, L-8 is extremely strong in ecological risk. Additionally, $\mathrm{Cu}$ also posed moderate ecological risks in two sites and only in the site L-1, L-5 has found to have moderate ecological risk.

The highest potential ecological risk indices for $\mathrm{Cr}$ were found in the dumping zone. For other metals $(\mathrm{Pb}$, $\mathrm{Ni})$ the ecological risk is low. There is no ecological risk in the sites due to $\mathrm{Cd}$. The potential ecological risk Index (PERI) is used as an indicator to check the ecological risk in soil. It is a comprehensive potential ecological risk index of a contaminated site. Potential ecological risk is for overall contaminated site.

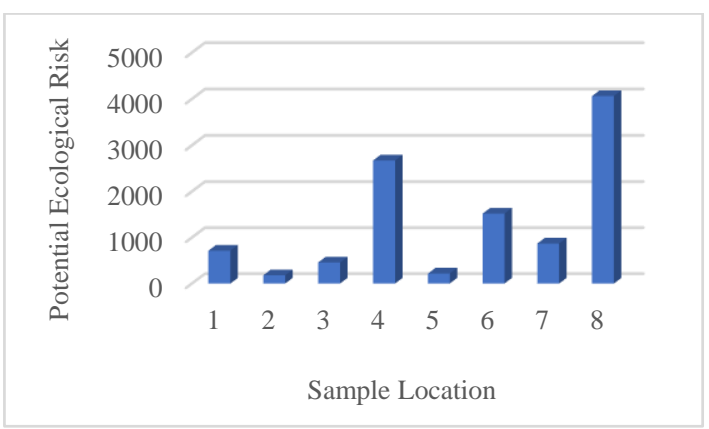

Fig. 4: Potential Ecological Risk Index of Various Metal

Five sites (L-3, L-4, L-6, L-7, L-8) among eight in TIED zone exhibited extremely strong potential ecological risk. The site L-2 is strong in ecological risk, whereas L-1, L-5 is very strong in ecological risk. The potential ecological risk values were clearly related to the degree of anthropogenic disturbance. Mainly the chrome tanning process in the tannery industries increases the $\mathrm{Cr}$ contamination.

\subsubsection{Geo Accumulation Index}

Geo accumulation index $\left(\mathrm{I}_{\mathrm{geo}}\right)$ is a parameter for determining contamination level of soil. 
Table 13

Geo Accumulation Index $\left(\mathrm{I}_{\mathrm{geo}}\right)$ of metals

\begin{tabular}{|c|c|c|c|c|c|}
\hline 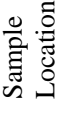 & $\mathrm{Cd}$ & $\mathrm{Cr}$ & $\mathrm{Pb}$ & $\mathrm{Cu}$ & $\mathrm{Ni}$ \\
\hline L-1 & -9.35 & 3.17 & 0.14 & 2.17 & -0.64 \\
\hline L-2 & -9.76 & 1.04 & 0.11 & 0.39 & -0.58 \\
\hline L-3 & & 2.63 & -3.15 & -1.87 & -2.45 \\
\hline L-4 & & 5.19 & -1.78 & -0.38 & -2.57 \\
\hline L-5 & -11.65 & 1.24 & -0.21 & 1.85 & -1.35 \\
\hline L-6 & & 4.38 & -1.61 & -1.63 & -2.83 \\
\hline L-7 & & 3.57 & -2.10 & -1.47 & -2.63 \\
\hline L-8 & & 5.80 & -0.66 & 0.01 & -2.61 \\
\hline
\end{tabular}

From the Table 13, it has been observed that $\mathrm{I}_{\text {geo }}$ value of $\mathrm{Cd}, \mathrm{Ni}$ is negative. It indicates that there is no contamination of soil for these heavy metals in the study sites.

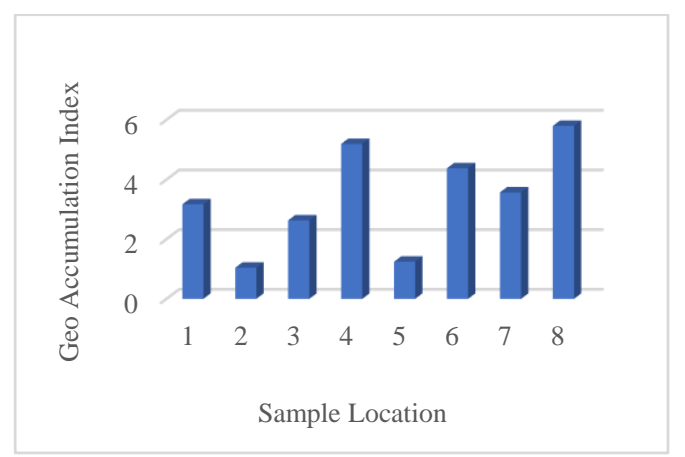

Fig. 5: Geo Accumulation Index of $\mathrm{Cr}$

$\mathrm{Cr}$ has significant $\mathrm{I}_{\text {geo }}$ value in all the sites which is clearly seen in the bar chart from Fig. 5. The selected area has severe $\mathrm{Cr}$ contamination. In L-2, L-5 Cr has moderate contamination. In L-3 contamination is moderate to strong. L-1. L-7 is strongly contaminated by Cr. L-6 has strong to extreme level contamination. Extremely $\mathrm{Cr}$ contamination is in the site of L-4 and L-8 which are the sites of dumping zone.

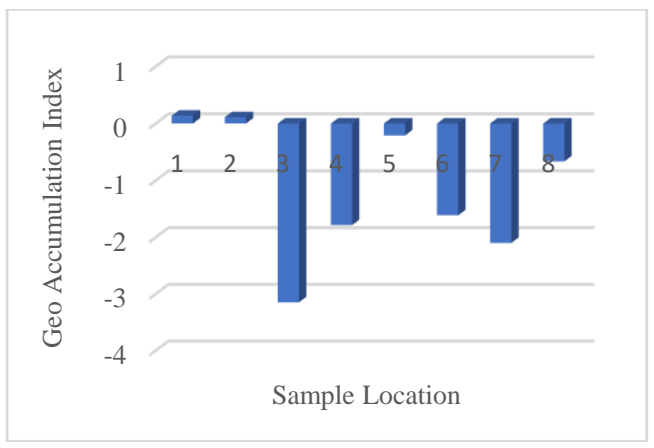

Fig. 6: Geo Accumulation Index of $\mathrm{Pb}$

From Fig. 6, it can be seen that, negative $\mathrm{I}_{\text {geo }}$ value of $\mathrm{Pb}$ has been found in the site L-3, L-4, L-5, L-6, L-
7, L-8, which means these sites' soils are not contaminated by $\mathrm{Pb}$. But in the riverside area L-1, L-2 has very little $\mathrm{Pb}$ contamination which falls in $\mathrm{I}_{\text {geo }}$ class 1 which means uncontaminated to moderately contamination.

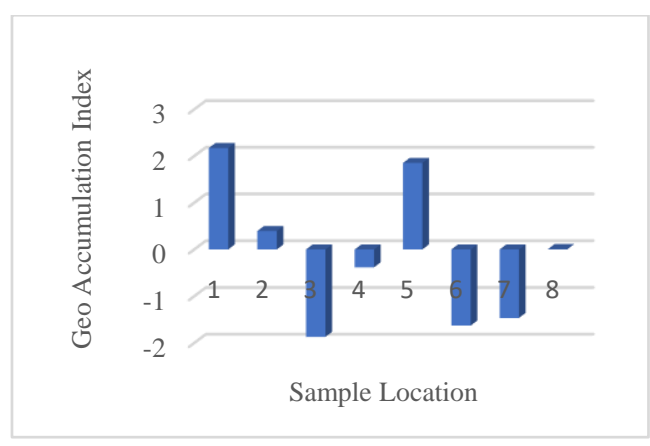

Fig. 7: Geo Accumulation Index of $\mathrm{Cu}$

It is clearly observed from the bar chart of Fig. 7, that L-1, L-2 and L-5 have $\mathrm{Cu}$ contamination. Other sites (L-3, L-4, L-6, L-7, L-8) have negative value which means these sites do not have $\mathrm{Cu}$ contamination.

\subsection{Pearson's correlation of heavy metals in the sediment}

The Pearson correlation coefficient was used to evaluate linear correlation between two variables $X$ and $Y$. The Pearson coefficient is between -1 and 1 , where -1 denotes a perfect negative correlation and 1 denotes a perfect positive correlation; 0 indicates the absence of a relationship.

Table 14

Correlation matrix between heavy metals in soil samples from Dhaleswari river

\begin{tabular}{|c|c|c|c|c|c|}
\hline & $\begin{array}{l}\mathrm{Cd} \\
(\mathrm{mg} / \mathrm{kg})\end{array}$ & $\begin{array}{l}\mathrm{Cr} \\
(\mathrm{mg} / \mathrm{kg})\end{array}$ & $\begin{array}{l}\mathrm{Pb} \\
(\mathrm{mg} / \mathrm{kg})\end{array}$ & $\begin{array}{l}\mathrm{Cu} \\
(\mathrm{mg} / \mathrm{kg})\end{array}$ & $\begin{array}{l}\mathrm{Ni} \\
(\mathrm{mg} / \mathrm{kg})\end{array}$ \\
\hline $\begin{array}{l}\mathrm{Cd} \\
(\mathrm{mg} / \mathrm{kg})\end{array}$ & 1.0 & & & & \\
\hline $\begin{array}{l}\mathrm{Cr} \\
(\mathrm{mg} / \mathrm{kg})\end{array}$ & -0.46 & 1 & & & \\
\hline $\begin{array}{l}\mathrm{Pb} \\
(\mathrm{mg} / \mathrm{kg})\end{array}$ & 0.86 & -0.26 & 1 & & \\
\hline $\begin{array}{l}\mathrm{Cu} \\
(\mathrm{mg} / \mathrm{kg})\end{array}$ & 0.71 & -0.33 & 0.78 & 1 & \\
\hline $\begin{array}{l}\mathrm{Ni} \\
(\mathrm{mg} / \mathrm{kg})\end{array}$ & 0.96 & -0.54 & 0.91 & 0.70 & 1 \\
\hline
\end{tabular}

$\mathrm{Cd}-\mathrm{Pb}(\mathrm{r}=.86), \mathrm{Cd}-\mathrm{Cu}(\mathrm{r}=.71), \mathrm{Cu}-\mathrm{Ni}(\mathrm{r}=.96), \mathrm{Ni}-$ $\mathrm{Cu}(\mathrm{r}=.78), \mathrm{Ni}-\mathrm{Pb}(\mathrm{r}=.91)$ are significantly correlated on the basis of Pearson's correlation. This indicates that those contaminants may have same or similar source input. $\mathrm{Cr}-\mathrm{Pb}, \mathrm{Cr}-\mathrm{Cu}, \mathrm{Cr}-\mathrm{Ni}$ are negatively correlated. 


\subsection{Heavy Metal Contamination and US EPA quality guideline}

Table 15

Comparison between USEPA sediment quality guideline and present

\begin{tabular}{|c|c|c|c|c|c|}
\hline (mg/kg dry weights) & $\mathrm{Cd}$ & $\mathrm{Cr}$ & $\mathrm{Pb}$ & $\mathrm{Cu}$ & $\mathrm{Ni}$ \\
\hline \multicolumn{6}{|l|}{ US EPA Sediment Quality Guideline } \\
\hline Not polluted & - & $<25$ & $<40$ & $<25$ & $<20$ \\
\hline Moderately polluted & - & $25-75$ & $40-60$ & $25-50$ & $20-50$ \\
\hline Highly polluted & $>6$ & $>75$ & $>60$ & $>50$ & $>50$ \\
\hline \multicolumn{6}{|l|}{ Present Study } \\
\hline Riverside of Industrial zone (mg/kg) & $0-.07$ & 299.7-1309.8 & $3.4-33$ & $13.1-216.3$ & $13.5-49.2$ \\
\hline Quality & not polluted & heavily polluted & not polluted & highly polluted & moderately polluted \\
\hline Dumping zone (mg/kg) & $0-0.01$ & $344.6-8093.8$ & $7.0-25.9$ & $15.5-173.4$ & $10.4-28.8$ \\
\hline Quality & not polluted & heavily polluted & not polluted & highly polluted & moderately polluted \\
\hline
\end{tabular}

\subsection{Spatial Distribution Analysis of Concentration and Contamination Factor}

The spatial distribution of concentration and contamination factor of $\mathrm{Cr}$ are shown in GIS maps.

Cr Concentration

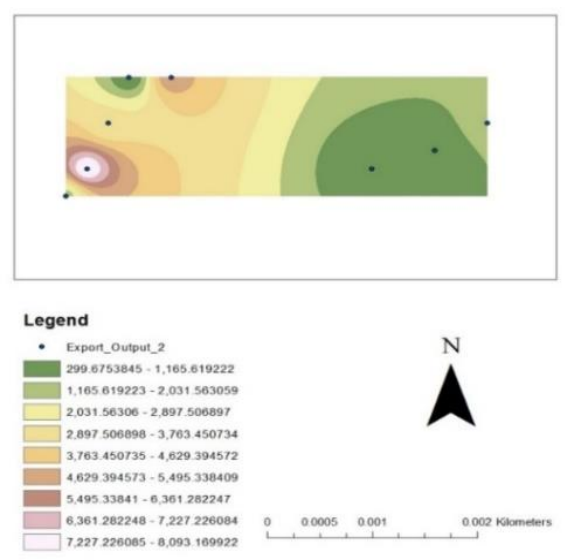

Fig. 8: Spatial Distribution of Cr Concentration in soil

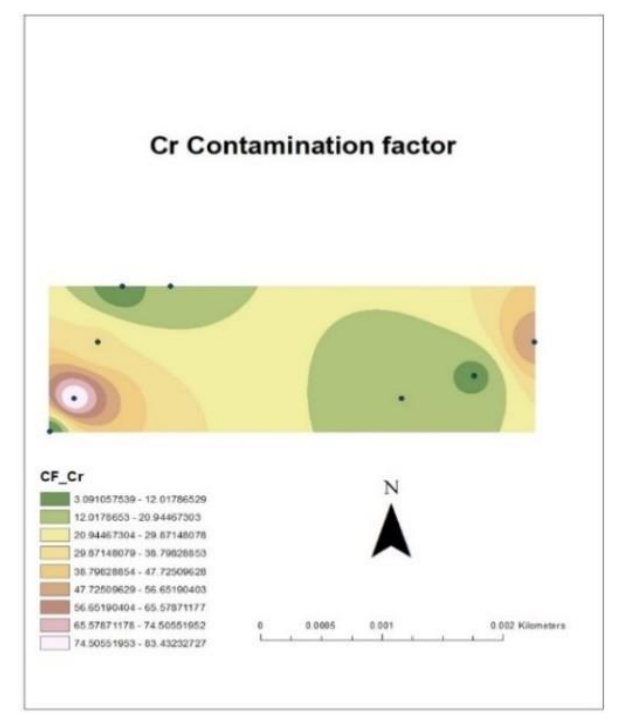

Fig. 9: Spatial Distribution of Cr CF in soil
Among all the metals, $\mathrm{Cr}$ is higher in concentration in the dumping zone. The colour variation from Fig. 8 shows the variation of $\mathrm{Cr}$ concentration in different locations. Cr concentration varies from 299.67 $8093.16 \mathrm{mg} / \mathrm{kg}$. The soil sample from white coloured location (L-8) has the highest concentration.

It is perceived from Fig. 9 that, $\mathrm{Cr}$ contamination factor is seen highest in the white coloured area which is adjacent to the dumping site. The contamination factor (CF) of Cr varies from 3.1 to 83.4.

\section{Conclusion}

Huge heavy metal contamination is in the soil of the tannery waste disposal site near Central Effluent Treatment Plant (CETP) at Savar. The concentration of metal element in the soil can be ordered as $\mathrm{Cr}>\mathrm{Cu}>\mathrm{Ni}>\mathrm{Pb}>\mathrm{Cd}$. The soil sample of a central point near CETP of the disposal site showed comparatively higher concentration than other sample collected from the larger distance with respect to that point.

\section{References}

[1] Kelly, J., Thornton, I., Simpson, P.R., (1996). Urban geochemistry: a study of influence of anthropogenic activity on heavy metal content of soils in traditionally industrial and nonindustrial areas of Britain. Appl. Geochem. 11, 363-370.

[2] López, T. D. M., Aide, T. M., \& Thomlinson, J. R. (2001). Urban Expansion and the Loss of Prime Agricultural Lands in Puerto Rico. AMBIO: A Journal of the Human Environment, 30(1), 49-54. doi: 10.1579/0044-7447-30.1.49

[3] Islam, M.R.; Lahermo, P.; Salminen, P.; Rojstaczer, S. and Peuraniemi, V. (2000). Lake leaching from tropical soils. Bangladesh Environmental Geology, 39: 1083108

[4] Banu, Z., Chowdhury, M. S. A., Hossain, M. D., and Nakagami, K. i. (2013). Contamination and Ecological Risk Assessment of Heavy Metal in the Sediment of Turag River, Bangladesh: An Index Analysis 
Approach. Journal of Water Resource and Protection, 05(02), 239-248.

[5] Naher, U. H. B., Islam, M. R., Mia, M. A. S., and Ali, M. F. (2018). Challenges and Prospects of Tannery Byproduct Industries (Glue, Gelatin, Poultry and Fish Feed Industries) in Bangladesh. International Journal of Science, Engineering and Technology Research (IJSETR).

[6] Islam, G.M.R., Khan, F.E., Hoque, M., Jolly, Y.N., (2014). Consumption of unsafe food in the adjacent area of Hazaribag tannery campus and Buriganga River embankments of Bangladesh: heavy metal contamination. Environ. Monit. Assess. 186, 72337244.

[7] Whitehead, P. G., Bussi, G., Peters, R., Hossain, M. A., Softley, L., Shawal, S., Alabaster, G. (2019). Modelling heavy metals in the Buriganga River System, Dhaka, Bangladesh: Impacts of tannery pollution control. Science of The Total Environment, 697. doi:10.1016/j.scitotenv.2019.134090
[8] Harris, A.R., Pickering, A.J., Harris, M., Doza, S., Islam, M.S., Unicomb, L., Luby, S., Davis, J.,Boehm, A.B., (2016). Ruminants contribute fecal contamination to the urban household environment in Dhaka, Bangladesh. Environ. Sci. Technol. 50, 46424649.

[9] J. Wilson, "Evaluation of Estuarine Quality Status at System Level with the Biological Quality Index and the Pollution Load Index (PLI)," Biology and Environment B, Vol. 103, 1987, pp. 47-59.

[10] L. Hakanson, "Ecological Risk Index for Aquatic Pollution Control, a Sedimentological Approach," Water Research, Vol. 14, No. 8, 1980, pp. 975-1001.

[11] Abrahim, G.M.S.; Parker, R.J. Assessment of heavy metal enrichment factors and the degree of contamination in marine sediments from Tamaki Estuary, Auckland, New Zealand. Environ. Monit. Assess. 2008, 136, 227-238.

[12] G. Muller, "The Heavy Metal Pollution of the Sediments of Neckars and Its Tributary: A stocktaking,” Chem. Zeit., Vol. 105, 1981, pp. 15 